\title{
Algal biomass and diversity in the upper subtidal at a pack-ice disturbed site in eastern Newfoundland*
}

\author{
D. W. Keats ${ }^{1}$, G. R. South ${ }^{1,2 * *}$, \& D. H. Steele ${ }^{1}$ \\ ${ }^{1}$ Department of Biology and ${ }^{2}$ Newfoundland Institute for Cold Ocean Science, Memorial University of Newioundland, \\ St. John's, Newioundland A1B 3X9, Canada
}

\begin{abstract}
Over a 5 yr period, the effect of physical disturbance by ice-scour on biomass, diversity and community composition in the shallow macro-algae zone of eastern Newfoundland was examined. In the absence of ice-scour, Alaria exculenta formed a canopy which shaded the substratum; few species co-existed and diversity was low. Winter and spring ice-scour, which was temporally and spatially patchy, removed the $A$. esculenta and made well-lighted rocky substratum available for colonization. Scoured patches were colonized by annual algae, resulting in an increase in species diversity. Diversity was greater when patchy scouring occurred throughout the winter-spring period, than when scouring was more restricted. Several species of annual algae persisted in patches among the unscoured $A$. esculenta, so diversity remained high during the summer following scouring.
\end{abstract}

\section{INTRODUCTION}

Ice-scour is a major physical disturbance to benthic marine biota in high latitudes (Wilce 1959, Ellis \& Wilce 1961, Stephenson \& Stephenson 1972, O'Clair et al. 1979, Mathieson et al. 1982). It affects littoral and sublittoral algae along much of the Newfoundland coast (excepting the south coast) (Hooper et al. 1980, Hooper 1981, Bolton 1983, South 1983), although its extent varies with year and locality. Here we present the results of a 5 yr quantitative study of the effects of ice-scour on a shallow water, high biomass benthic sublittoral algal community at an open Atlantic coast site in Conception Bay, Newfoundland.

In order to understand community patterns it is necessary to determine how environmental factors affect the distribution and abundance of species. Although ice-scour has a major impact on subtidal biota, its effect on species composition and diversity of the algal community remain little explored. Questions addressed by this research are: (1) How are biomass, dominance-diversity patterns, and species composition

\footnotetext{
- Newfoundland Institute for Cold Ocean Science Contribution No. 82

- Present address: Huntsman Marine Laboratory, St. Andrews, New Brunswick EOG 2X0, Canada
}

of the benthic macro-algal community affected by icescour? (2) Is the community affected differently if scouring occurs at different times of the year?

The study area is located south of the maximum extent of in situ generated winter pack ice (Dinsmore 1972). Ice drifts south with the Labrador Current. If northeasterly winds predominate in the January-June (or later) period, ice moves inshore and scours intertidal and upper subtidal substrata (Hooper 1981). Icescour does not occur in all years, and its onset and duration vary from year-to-year. The study area has the bimodal vertical distribution of sublittoral seaweed biomass typical for the open Atlantic coast of Newfoundland (Keats 1985). There is a shallow zone of high fleshy algal biomass, an intermediate, heavily grazed zone with low fleshy algal biomass and numerous sea urchins (Strongylocentrotus droebachiensis [O. F. Muell.]), and a deeper zone of high fleshy algal biomass dominated by Agarum cribrosum (Mert.) Bory and Ptilota serrata Kuetz. (Keats et al. 1982, Himmelman 1985). The width of the shallow zone may vary seasonally, depending upon the effect of wave action on urchin foraging (Himmelman 1985).

Many of the species which colonize during succession in benthic communities frequently show seasonal recruitment; temporal patterns of disturbance may 
therefore influence subsequent community composition. Ice-scour occurred in 3 out of 5 years during the present study, and year-to-year differences in the time of its occurrence permitted a preliminary determination of seasonal scour effects on the algal community.

\section{MATERIALS AND METHODS}

Two sites characteristic of the open Atlantic coast of Newfoundland (Hooper et al. 1980, South 1983) were chosen. They were located $1 \mathrm{~km}$ apart in Conception Bay $\left(46^{\circ} 40^{\prime} \mathrm{N}, 52^{\circ} 50.2^{\prime} \mathrm{W}\right)$. Sea temperatures in the study area range from $-1.8{ }^{\circ} \mathrm{C}$ in winter to $15^{\circ} \mathrm{C}$ in summer (Hooper et al. 1980), with considerable interannual variation in the summer maximum (Steele 1975). Ice-scour effects were studied from 1979 to 1983. In 1979 ice-scour occurred in April, in 1980 in February, and in 1983 from February to April. There was no ice-scour in 1981 and 1982.
A sample of from five to ten $0.1 \mathrm{~m}^{2}$ quadrats per sample date was taken from each site. Quadrats were placed by blind casting from the surface. Plant and animal material was harvested by hand and placed into $0.5 \mathrm{~mm}$ mesh collecting bags. The remaining material was then scraped from the substratum, and collected using an air dredge fitted with a $0.5 \mathrm{~mm}$ (mesh size) collecting tube. Samples were gathered in July 1979, May and October 1980, May and July 1981, July 1982, and July 1983. Because of the difficulty of obtaining many samples in the shallow zone (due to wave action), data from May and October 1980 and May and July 1981 were pooled within years for analysis of diversity trends, as were the data from the 2 sites. The only significant difference between these dates within years is that Ectocarpus spp. (species with low biomass - see Table 1) was more abundant during October than May of 1980 (t-test, $\mathrm{p} \leq .05$ ). Frequent observations of the species present were also made throughout the year for the duration of the study.

Table 1. Biomass (arithmetic mean) of algal species by year. Numbers in parentheses are $\log _{10}$ mean $\pm \mathrm{SE}$; superscript on year indicates month during which ice-scour occurred; + indicates presence but too little to weigh

\begin{tabular}{|c|c|c|c|c|c|}
\hline Species & $\begin{array}{c}1979 \text { Apr } \\
(\mathrm{N}=10)\end{array}$ & $\begin{array}{c}1980^{\mathrm{Feb}} \\
(\mathrm{N}=14)\end{array}$ & $\begin{array}{c}1981 \\
(N=13)\end{array}$ & $\begin{array}{c}1982 \\
(N=20)\end{array}$ & $\begin{array}{c}1983 \text { Feb-Apr } \\
(N=20)\end{array}$ \\
\hline Chordaria flagelliformis & $1329.4(2.95 \pm .18)$ & $92.1(1.22 \pm .25)$ & $1.99(.14 \pm .11)$ & $14.3(.25 \pm .14)$ & $303.9(1.59 \pm .24)$ \\
\hline Alaria esculenta & $718.3(2.15 \pm .30)$ & $1597.5(3.11 \pm 0.08)$ & $5032.2(3.34 \pm .31)$ & $5780.0(3.28 \pm 0.24)$ & $1869.6(2.78 \pm .24)$ \\
\hline Saccorhiza dermatodea & $7.6(.46 \pm .19)$ & $824.4(2.17 \pm .31)$ & 0.0 & $16.7(0.19 \pm 0.14)$ & $179.8(1.16 \pm .28)$ \\
\hline Devaleraea ramentacea & $119.4(1.35 \pm .31)$ & $177.3(1.31 \pm .28)$ & $6.7(.33 \pm .16)$ & $.61(.11 \pm .05)$ & $38.8(.84 \pm .17)$ \\
\hline Spongomorpha arcta & $31.1(1.16 \pm 0.23)$ & $231.8(1.11 \pm .30)$ & $.55(.09 \pm .07)$ & 0.0 & $42.5(1.13 \pm .17)$ \\
\hline Spongomorpha aeruginosa & $14.7(.95 \pm .17)$ & $2.39(.40 \pm .09)$ & 0.0 & 0.0 & $4.5(.39 \pm .11)$ \\
\hline Dictyosiphon foeniculaceus & $28.8(1.29 \pm .15)$ & 0.0 & 0.0 & $0.90(.06 \pm .06)$ & $92.6(1.32 \pm .22)$ \\
\hline Laminaria digitata & $10.7(.30 \pm .22)$ & $3.18(.19 \pm .12)$ & $157.1(.46 \pm .31)$ & $14.3(.33 \pm .15)$ & $118.8(.86 \pm .24)$ \\
\hline Scytosiphon lomentaria & $18.8(.90 \pm .18)$ & $17.5(.56 \pm .19)$ & 0.0 & $.33(.07 \pm .04)$ & $3.12(.27 \pm .10)$ \\
\hline Petalonia fascia & $11.7(.87 \pm .17)$ & $22.2(0.66 \pm .20)$ & + & $99(.08 \pm .07)$ & $.65(.12 \pm .05)$ \\
\hline Petalonia zosterifolia & $.11(.04 \pm .02)$ & $11(.04 \pm .02)$ & 0.0 & 0.0 & + \\
\hline Phycodrys rubens & 0.0 & 0.0 & 0.0 & 0.0 & + \\
\hline Pilayella littoralis & $.75(.21 \pm .05)$ & $4.85(.33 \pm .14)$ & $.24(.07 \pm .04)$ & + & $1.96(.17 \pm .08)$ \\
\hline Polysiphonia flexicaulis & $.10(.03 \pm .03)$ & $.54(.09 \pm .06)$ & $.38(.08 \pm .06)$ & + & 0.0 \\
\hline Polysiphonia urceolata & $11.7(.91 \pm .15)$ & $15.1(.71 \pm .19)$ & $51.6(.80 \pm .25)$ & $14.0(.54 \pm .15)$ & $47.2(1.13 \pm .18)$ \\
\hline Porphyra sp. & + & + & 0.0 & 0.0 & + \\
\hline Ptilota serrata & + & 0.0 & 0.0 & + & 0.0 \\
\hline Punctaria plantaginea & $1.96(.30 \pm .12)$ & $.57(.07 \pm .07)$ & 0.0 & 0.0 & + \\
\hline Rhodomela confervoides & $.23(.05 \pm .05)$ & + & $.88(.08 \pm .08)$ & $.53(.08 \pm .06)$ & $1.16(.07 \pm .07)$ \\
\hline Scagelia corallina & + & + & + & + & $.20(.06 \pm .03)$ \\
\hline Sphacelaria plumosa & 0.0 & 0.0 & 0.0 & 0.0 & + \\
\hline Ulva lactuca & 0.0 & 0.0 & 0.0 & 0.0 & + \\
\hline Ulvaria obscura & + & $1.29(.16 \pm .09)$ & $.30(.07 \pm .05)$ & 0.0 & 0.0 \\
\hline Antithamnionella floccosa & + & 0.0 & 0.0 & 0.0 & 0.0 \\
\hline Ceramium rubrum & $.13(.04 \pm .03)$ & + & $5.59(.18 \pm .14)$ & + & $14(.10 \pm .07)$ \\
\hline Chorda tomentosa & $.58(.08 \pm .08)$ & $4.4(.21 \pm .13)$ & 0.0 & 0.0 & $65.7(.97 \pm .22)$ \\
\hline Cystoclonium purpureum & 0.0 & + & 0.0 & 0.0 & 0.0 \\
\hline Desmarestia spp. & 0.0 & 0.0 & $17.9(20 \pm .18)$ & $2.4(.08 \pm .08)$ & 0.0 \\
\hline Ectocarpus spp. & $1.90(.28 \pm .12)$ & $28.3(.78 \pm .23)$ & $12(.04 \pm .03)$ & $12.7(.34 \pm .14)$ & $30.1(.85 \pm .17)$ \\
\hline Eudesme virescens & 0.0 & 0.0 & 0.0 & 0.0 & + \\
\hline Giffordia granulosa & + & 0.0 & 0.0 & + & 0.0 \\
\hline Monostroma grevilleii & 0.0 & 0.0 & 0.0 & + & + \\
\hline Palmaria palmata & + & $15(0.4 \pm .04)$ & $.40(.07 \pm .06)$ & $4.13(.03 \pm .01)$ & $68.4(.83 \pm .22)$ \\
\hline
\end{tabular}


Variables measured included total (except for crustose species) non-calcareous (= fleshy) macro-algal biomass, and biomass of individual species. Sorting and identification were with fresh or frozen material. Freezing the specimens did not affect wet weight values. Algae were sorted by species, blotted for 5 min on paper towel to remove surface water, and wet weighed.

Examination of scatter plots of standard deviation vs mean biomass, and frequency plots showed considerable heteroscedasticity and deviation from normality. $\log _{10}$ transformations of the data were therefore performed prior to calculating standard errors (Sokal \& Rohlf 1969). Dominance-diversity (= species relative abundance) curves (Whittaker 1965, May 1981) were generated using the percent of biomass for each species. Diversity $\left(\mathrm{H}^{\prime \prime}\right)$ and dominance $(1-\mathrm{J})$ were calculated for biomass data as suggested by Wilhm (1968). Curves and indices were produced by a Fortran-77 program implemented on a Digital Equipment Corporation Vax 11/780 computer. Species richness represents the total number of species present in all samples.

\section{RESULTS}

\section{Description of ice-scour episodes}

In 1979 first-year ice, approximately $60 \%$ cover, drifted into Conception Bay during mid-April. It was present for $6 \mathrm{~d}$, when wind again moved it offshore. Approximately $60 \%$ of the substratum in the 0 to $2 \mathrm{~m}$ (below MLW) depth range was unevenly scoured. In 1980 first-year ice (approximately $60 \%$ cover) moved into the bay during the second week of February. It was present for $4 \alpha$, after which no further scouring occurred. About $40 \%$ of the substratum in the 0 to $2 \mathrm{~m}$ depth range received patchy scouring.

In 1983 first-year ice moved into the bay during the week of February 14, and by February 18 ice cover exceeded $90 \%$. From February 18 to March 24 ice was present in the vicinity of the study site. It moved 2 to $5 \mathrm{~km}$ offshore on March 24, but returned on April 9. It moved off again on April 12. Thereafter ice movement was erratic for the remainder of April, and by the first week in May all ice was gone. Thus during 1983 there were essentially 2 major episodes of ice-scouring (Feb 18 to Mar 24, and Apr 9 to Apr 30).

In all 3 years ice-scour was not evenly distributed. With the exception of crevices, the intertidal and upper ca $0.8 \mathrm{~m}$ of the subtidal were completely scoured. The lower ca $1 \mathrm{~m}$ (over $0.5 \mathrm{~m}$ depth) of the shallow algae dominated zone, and the sea urchin dominated zone below, were largely unscoured. The intermediate 1 to $1.5 \mathrm{~m}$ wide portion (over $0.5 \mathrm{~m}$ depth) of the algae dominated zone was patchily scoured (approximately 40 to $50 \%$ of the substratum). Significant ice-scour was therefore confined to the intertidal and the upper subtidal.

\section{Macro-algal biomass}

Total fleshy macro-algal biomass showed no significant differences among years (Fig. 1). In the absence of ice-scour biomass was more unevenly distributed than it was during years in which ice-scour occurred. This was so because the canopy of Alaria

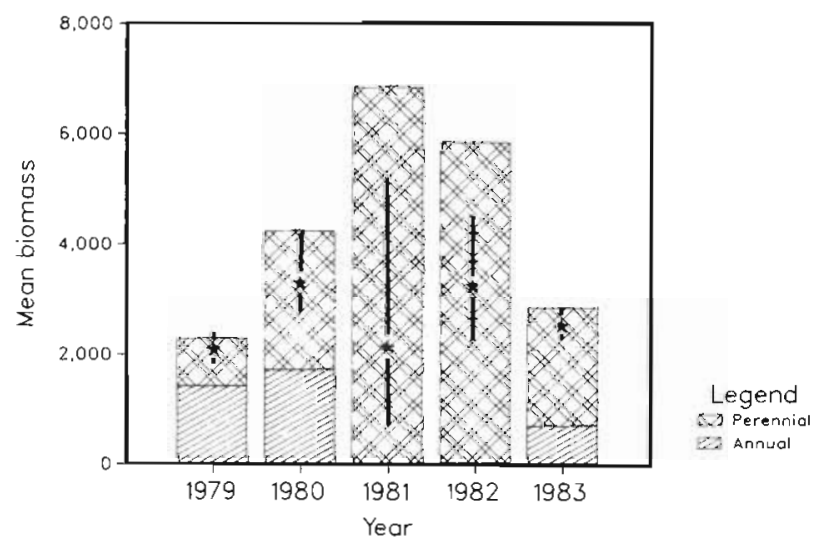

Fig. 1. Arithmetic means (histograms) of total fleshy macroalgal biomass of annuals and perennials for each year of the study. Stars and vertical lines: geometric means $\pm 1 \mathrm{SE}$

esculenta (L.) Grev. was sufficiently dense to exclude light from the understorey, but holdfast attachments (and therefore biomass) were patchy. Light levels under the canopy were less than $1 \%$ of those at the canopy surface, as measured using a Sekonic Marine light meter. This presumably prevented occupancy of the space among the $A$. esculenta holdfasts by other species. Following ice-scour the substratum was covered by an even distribution of smaller algae, resulting in a more even distribution of biomass. These trends are demonstrated by the large standard errors for total algal biomass during years in which no icescour occurred (Fig. 1). The overall arithmetic mean biomass at 0 to $2 \mathrm{~m}$ was $4413 \mathrm{~g} \mathrm{~m}^{2}\left(\log _{10}\right.$ mean $=3.40$, $\mathrm{SE}=0.59, \mathrm{~N}=77$ ).

\section{Species composition}

Ice-scouring during April of 1979 removed the dominant Alaria esculenta, and Chordaria flagelliformis (O. F. Muell.) C. Ag became the dominant alga in scoured patches (see below). Its epiphyte Dictyosiphon foeniculaceous (Huds.) Grev, also increased in biomass 
(Table 1). Much of the C. flagelliformis and $D$. foeniculaceous was removed by ice-scouring during February of 1980. A. esculenta (recruited to scoured patches during late February and early March 1980) and Saccorhiza dermatodea (Pyl.) J. Ag. (recruited during late March 1980) were abundant in the scoured patches. $S$. dermatodea became scenescent and was largely gone by February of 1981. At this time colonization by new $A$. esculenta occurred, this species ultimately comprising $95 \%$ of the biomass (Fig. 2). In the absence of ice-scour during 1981 and $1982 A$. esculenta remained the dominant alga. The first phase of ice-scour during 1983 removed much of the large $A$. esculenta. Juvenile $A$. esculenta appeared in the scoured patches during February and early March, and S. dermatodea recruited during late March. Scouring of the recruits during March and April resulted in the clearance of substratum, which was then colonized by C. flagelliformis. Some new A. esculenta also appeared, but observations indicate that recruitment was lighter than it was during February/March. By the summer of 1983 a diverse community existed, made up of a mixture of species which had colonized patches of substratum scoured at different times

Certain species were more abundant during all years in which ice-scour occurred, irrespective of its timing (e.g. Chorda tomentosa Lyngb., Ectocarpus spp., Devalaraea ramentacea (L.) Guiry, Spongomorpha arcta (Dillw.) Kuetz., Spongomorpha aeruginosa (L.) Hoek. and Scytosiphon lomentaria (Lyngb.) (Link). Petalonia fascia (O. F. Muell.) O. Kuntze is also in this category, but it was extremely patchy during 1983, and not encountered in many samples. Other species which were present in low abundance during the study, and not obviously affected by ice-scour, are presented in Table 1. Palmaria palmata (L.) O. Kuntze was most abundant during 1983, but it only occurred as an epiphyte on the stipes of old $A$. esculenta sporophytes. As such its presence was not dependent on the occurrence of ice-scour.

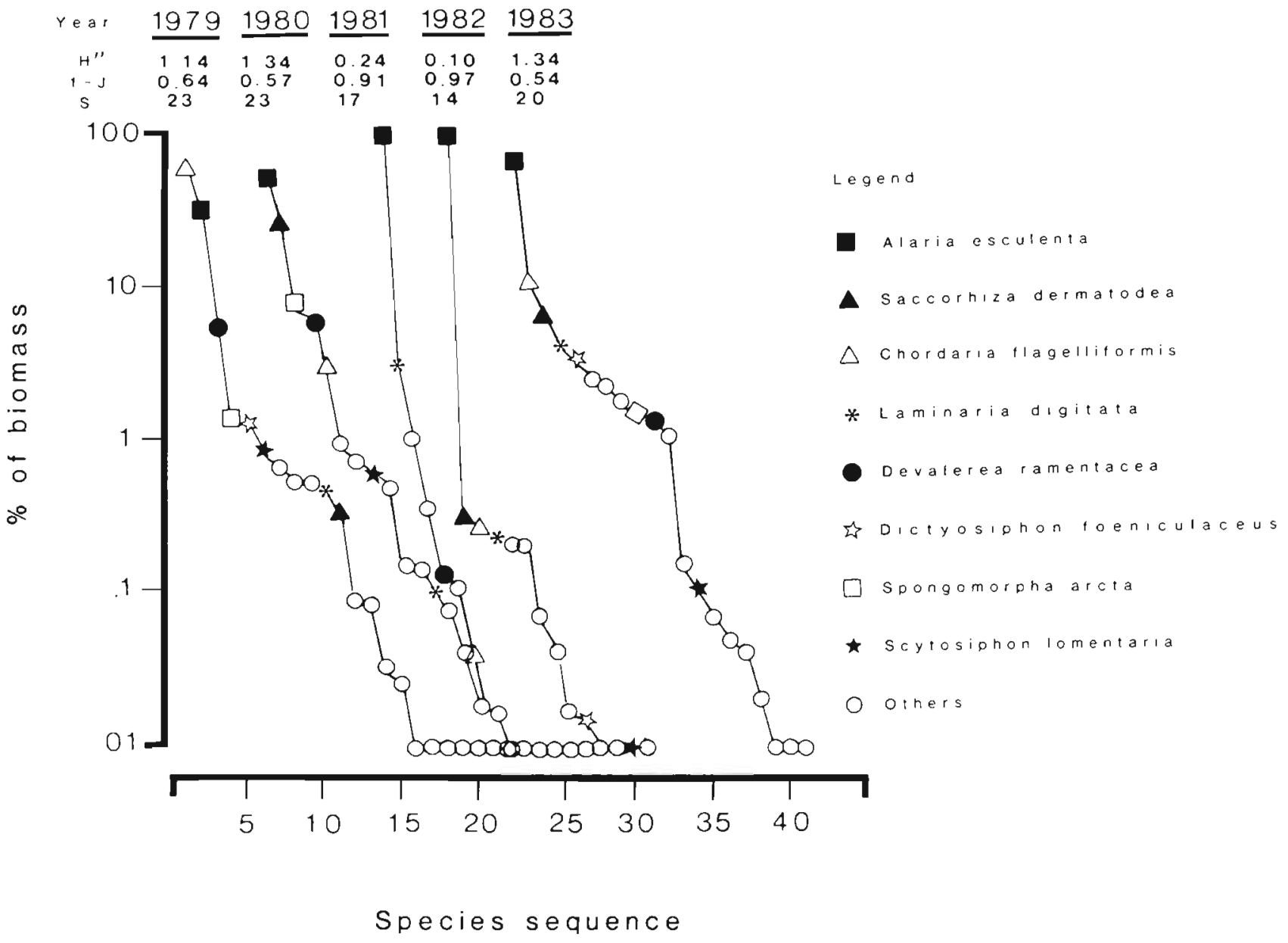

Fig. 2. Species relative abundance curves, and indices of diversity $\left(\mathrm{H}^{\prime \prime}\right)$, dominance (1-J) and species richness (S) for each year of the study 


\section{Species richness and dominance}

Fig. 2 shows species relative abundance curves as well as indices of diversity $\left(\mathrm{H}^{\prime \prime}\right)$, dominance $(1-\mathrm{J})$ and species richness (S). Following ice-scour there was an increase in the number of species with intermediate relative abundance. In the absence of ice-scour, dominance of biomass by Alaria esculenta was high. Species richness and diversity were therefore greatest during summers following ice-scour episodes. To determine the effect on dominance, diversity and species richness of heavy ice-scour, and of the time of its occurrence, data from samples taken during 1979 and 1983 were analysed, with quadrats from patches of old $A$. esculenta excluded in calculating the means used to generate the species relative abundance curves (Fig. 3). Species richness in scoured patches showed no relation with the timing of ice-scour (Fig. 3). Nevertheless, dominance was lower and the evenness of biomass distribution among species was greater in patches scoured throughout the February-April 1983 period. Chordaria flagelliformis comprised $77 \%$ of biomass in patches scoured during April. A. esculenta was the species with highest biomass, but Saccorhiza dermatodea was also abundant in patches scoured during February (Fig. 2). A mosaic of patches scoured in different months contributed to a greater diversity in 1983.

\section{Comparison of annual and perennial species}

The numbers of annual and perennial species were determined for each year (Fig. 4). The assignment to 'annual' or 'perennial' status (Feldmann 1966) was based on information provided by Taylor (1957) and South \& Hooper (1980). Both the number of annual species and their biomass were greater in years during which ice-scour occurred. The number of perennials showed no relation with ice-scour episodes (Fig, 4), but the biomass of perennials was greater in the absence of ice-scour.

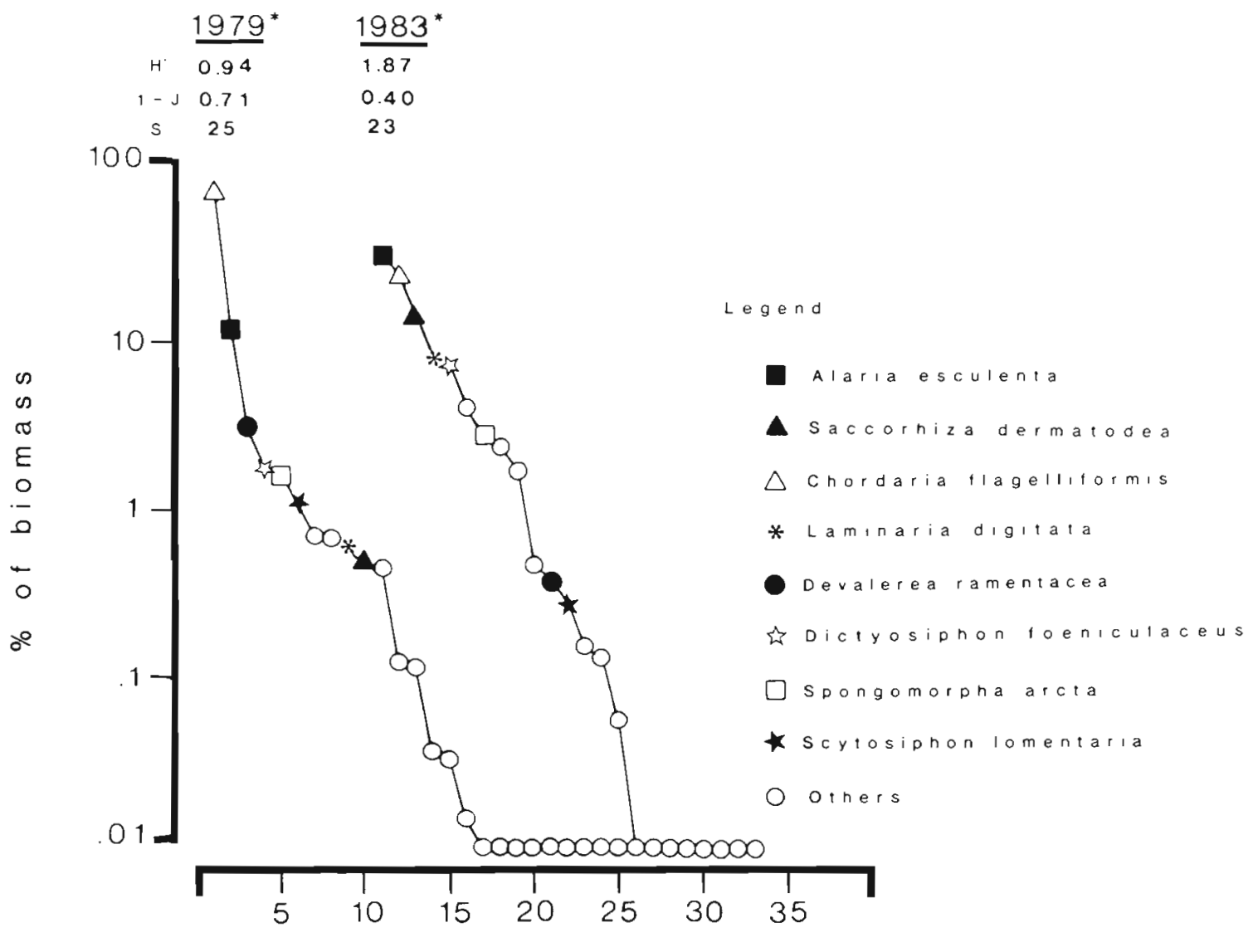

Species sequence

Fig. 3. Species relative abundance curves for 1979 and 1983, with quadrats from patches of old Alaria esculenta excluded in calculating the means used to generate the curves 


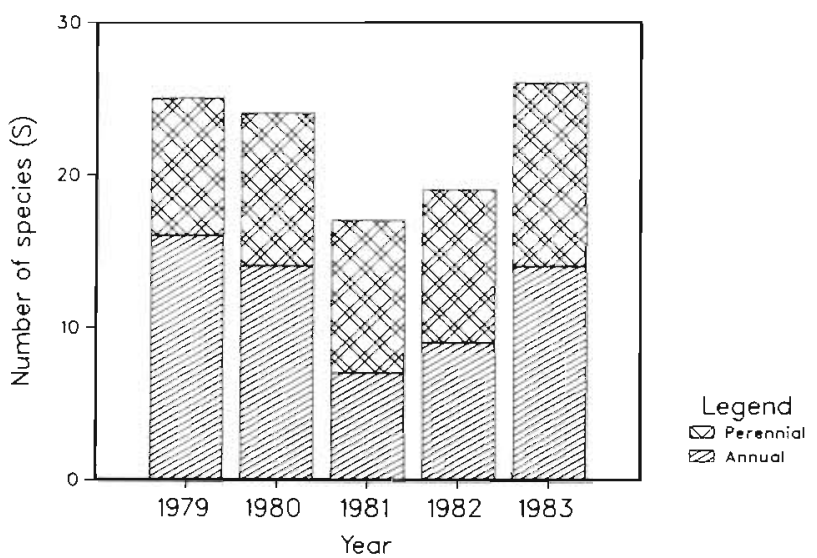

Fig. 4. Number of species of annual and perennial algae for each year of the study

\section{DISCUSSION}

Disturbance influences many aspects of community structure (Sousa 1984). At low levels of disturbance, domination of a limiting resource occurs, and at extreme levels of disturbance most species are eliminated. Highest diversity (numbers of species and/or the evenness of biomass distribution among species) therefore occurs at intermediate levels of disturbance. In the absence of disturbance by ice at the present study site, biomass in the shallow water was dominated by Alaria esculenta, and the number of species of intermediate relative abundance was low.

Low light levels beneath the Alaria esculenta canopy suggest that light was the limiting resource, while primary space was not. Removal of the $A$. esculenta canopy by ice-scour made light available. allowing the colonization and/or growth of species unable to grow in the dimly-lit understorey. Light limitation of the growth of understorey species has been demonstrated for other canopy-forming algae, including Macrocystis pyrifera (Pearse \& Hines 1979), Laminaria hyperborea (Harkin 1981), and Laminaria groenlandica (Duggins 1980). Domination of the shallow sublittoral by $A$. esculenta on moderately to fully exposed shores is widespread around Newfoundland (South 1983, Himmelman 1985). An Alaria zone is frequently found at sites with similar wave exposure in Nova Scotia (Mann 1972), Labrador (Wilce 1959, Keats pers. obs.), Greenland (Lund 1959), Iceland (Munda 1975), the Faroes (Price \& Farnham 1982), Norway (Jaasund 1965) and parts of the British Isles (Norton et al. 1977). The reasons for the development of abundant Alaria must differ in different geographical areas.

This study shows that in eastern Newfoundland dominance by Alaria esculenta is mediated in part by an interaction between the occurrence, timing, and severity of ice-scour episodes (Fig. 5). A. esculenta is

This study

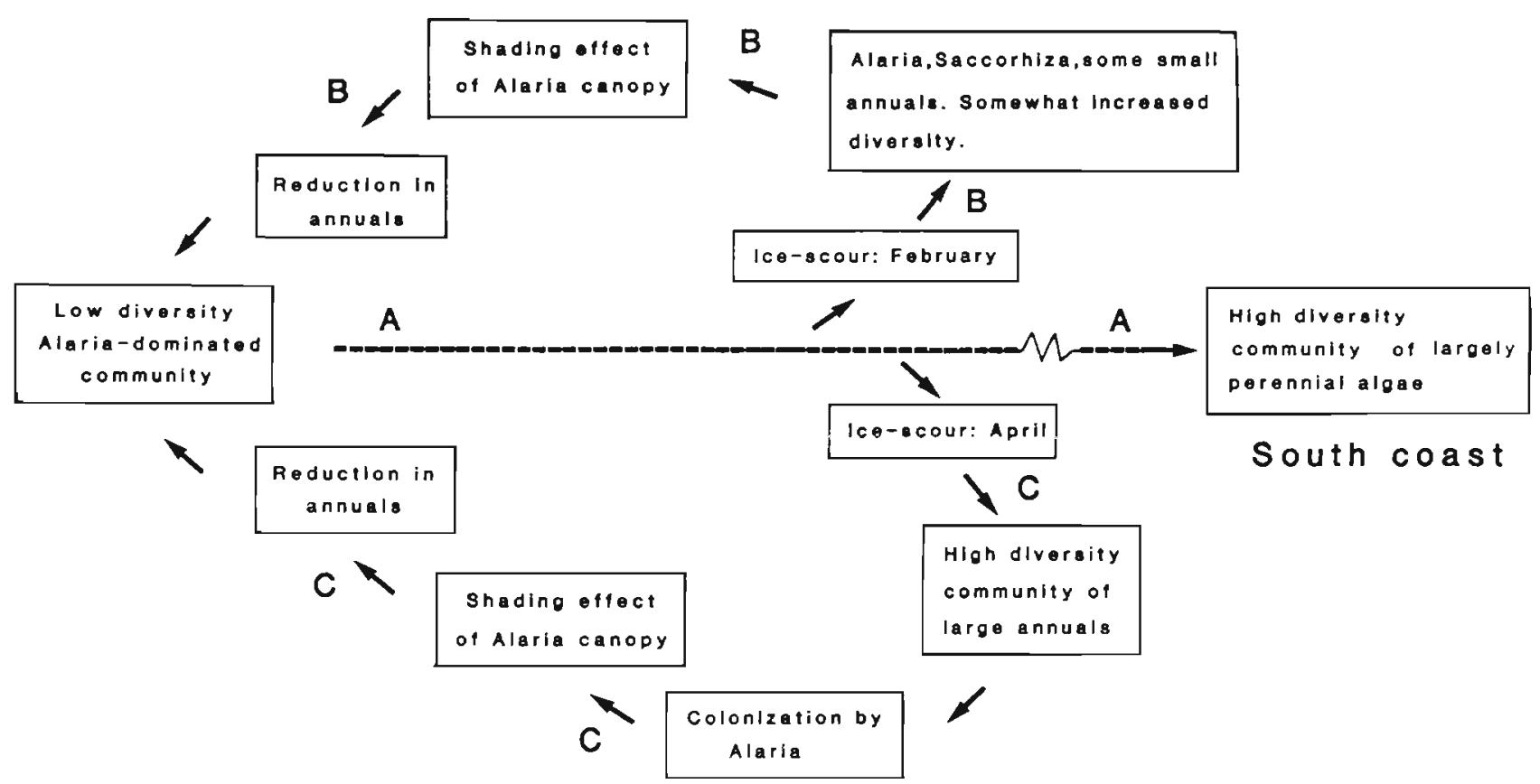

Fig. 5. Conceptual representation of the effect of ice-scour on an open coast community in eastern Newfoundland. Pathway 'A' is interrupted by periodic ice-scour, and ' $\mathrm{B}$ ' or ' $\mathrm{C}$ ' predominates depending on the time of scouring 
partially removed by ice-scour but returns to dominate after $1 \mathrm{yr}$, or even in the same year if scouring is early. It grows rapidly and forms a dense shade-producing canopy. On the south coast of Newfoundland, where ice-scouring is rare, such extreme domination by $A$. esculenta does not occur. The shallow sublittoral at sites receiving moderate to full exposure to wave action frequently has a rich algal community consisting of large perennial species (Keats pers. obs., Hooper pers. comm.). A. esculenta is an important component of that community, but along with many other abundant species. Presumably these species are less able to tolerate the frequent ice-scour episodes which occur in eastern Newfoundland. These contrasting observations from the south coast suggest that although the short-term effect of ice-scour is to change a low diversity $A$. esculenta dominated community to a diverse community of annuals, the high degree of domination by $A$. esculenta may depend on ice-scour (Fig. 5). The suggestion that diversity would increase with time in the complete absence of ice-scour is supported by the results of a study by O'Clair et al. (1979), who showed that species richness and diversity on scoured shores were considerably lower than they were on unscoured shores in the Pribilof Islands, Alaska. The hypothesis warrants critical testing, particularly with studies conducted on the south coast of Newfoundland and in Labrador. Studies on the northeast coast and in the Gulf of St. Lawrence would also be worthwhile as a means of determining the nature and rôle of ice-scour on different parts of the Newfoundland coast.

Annual algae were most abundant following icescour. Other studies of succession following disturbance, manual clearing or the provision of new substratum have also shown that annual species are generally the initial colonizers, and are most abundant in periodically disturbed areas (Lee 1966, Dayton 1975, Foster 1975, Emerson \& Zedler 1978, Sousa 1979a, b). Except for Devaleraea ramentacea and Saccorhiza dermatodea, all of the species that yielded greater biomass after ice-scour are able to reproduce and disperse without sexual reproduction (Bold \& Wynne 1978, Tanner 1981, van der Meer 1981, Littler \& Littler 1983). This is advantageous for rapid colonization of disturbed habitats (Littler \& Littler 1980). These species also have stages capable of inhabiting small irregularities in the substratum. By producing uprights directly they have an advantage over species which have to colonize from outside the scoured area.

Chordaria flagelliformis was prominent in patches scoured during April. Probyn \& Chapman $(1982,1983)$ have demonstrated that $C$. flagelliformis has the ability to take advantage of short-term pulses in the availability of dissolved nitrogen, as well as to scavenge nitrate at very low concentrations. C. flagelliformis is there- fore well adapted for colonization and growth in areas scoured during the spring, just prior to a major decrease (Sandeman 1982) in nutrient concentration. Nutrient kinetics of the other species observed during the study have not been investigated.

A potential problem with the present interpretation is that the lag period between ice-scour and sampling differed for the $3 \mathrm{yr}$ in which ice-scour occurred. This effect is confounded within the effects of the timing of scour. Observations of colonization shortly after icescour, however, indicate that any effects of this lag period are slight. The actual values of $\mathrm{H}^{\prime \prime}$ and $1-\mathrm{J}$ may have been different if the lag period had been held constant, but it is unlikely that the relative distribution of biomass among the more abundant species or the overall conclusions would change.

Acknowledgements. We acknowledge the financial support of NSERC strategic grant G-0233 and NSERC operating grants A-4648 and A-1732, and an Environment Canada, Department of Fisheries and Oceans, Science Subvention Grant to G. R. South and D. H. Steele. The following persons gave technical and diving assistance: Don Chafe, Clyde Collier, Steve Dawson, Ross Downey, Cheryl Gullason, Kathy Knight, Keith Mercer, Sandra O'Neill, Peter Noble, and lan Roy. We thank R. Hooper, A. Mathieson, A. Whittick, R. Wilce, and 3 anonymous reviewers for suggesting improvements to the manuscript.

\section{LITERATURE CITED}

Bold, H C., Wynne, M. J. (1978). Introduction to the algae. Prentice-Hall, Inc., Englewood Cliffs, New Jersey

Bolton, J. J. (1983). Effects of short-term ice scouring on a Newfoundland rocky shore community. Astarte 12: 39-48

Dayton, P. K. (1975). Experimental evaluation of ecological dominance in a rocky intertidal algal community. Ecol. Monogr. 45: 137-159

Dinsmore, R. P. (1972). Ice and its drift into the Atlantic Ocean. International Commission for the Northwest Atlantic Fisheries (ICNAF) Spec. Publ. 8: 89-128

Duggins, D. O. (1980). Kelp beds and sea otters: an experimental approach. Ecology 61: 447-453

Ellis, D. V., Wilce, R. T. (1961). Arctic and subarctic examples of intertidal zonation. Arctic 14: 224-235

Emerson, S. E., Zedler, J. B. (1978). Recolonization of intertidal algae: an experimental study. Mar. Biol. 44: 315-324

Feldmann, J. (1966). Les types biologiques d'algues marine benthique. Mem. Soc. Bot. France (Colloque de Morphologie, 1965) 45-60

Foster, M. S. (1975). Algal succession in a Macrocystis pyrifera forest. Mar. Biol. 32: 313-329

Harkin, E. (1981). Fluctuations in epiphyte biomass following Laminaria hyperborea canopy removal. Proc. Int. Seaweed Symp. 10: 303-308

Himmelman, J. H. (1985). Urchin feeding and macroalgal distribution in Newfoundland, eastern Canada. Naturaliste can. 111: 337-348

Hooper, R. G. (1981). Recovery of Newfoundland benthic marine communities from sea ice. Proc. Int. Seaweed Symp. 8: 360-366

Hooper, R. G., South, G. R., Whittick, A. (1980). Ecological and phenological aspects of the marine phytobenthos of 
the island of Newfoundland. In: Irvine, D. E. G., Farnham, W. F. (ed.) The shore environment, Vol. 2, Ecosystems Price, J. H. (ed.). Academic Press, London, p. 395-423

Jaasund, E. (1965). Aspects of the marine algal vegetation of north Norway. Bot. Gothoburg 4: 1-174

Keats, D. W (1985). The effects on benthic marine macroalgae and herbivorous invertebrates of the experimental removal of sea urchins at a periodically ice-scoured sublittoral site in eastern Newfoundland. Ph. D. thesis, Memorial Univ. Nfld., St. John's, Newfoundland

Keats, D. W., South, G. R., Steele, D. H. (1982). The occurrence of Agarum cribrosum (Mert.) Bory (Phaeophyta, Laminariales) in relation to some of its competitors and predators in Newfoundland. Phycologia 21: 189-191

Lee, R. K. S. (1966). Development of marine benthic algal communities on Vancouver Island. In: Taylor, R. L., Ludwig, R. A. (ed.) The evolution of Canada's flora. Univ. Toronto Press, Toronto

Littler, M. M., Littler, D. S. (1980). The evolution of thallus form and survival strategies in benthic marine macroalgae: field and laboratory tests of a functional form model. Am. Nat. 116: 25-44

Littler, M. M., Littler, D. S. (1983). Heteromorphic life-history strategies in the brown alga Scytosiphon lomentaria (Lyngb.) Link. J. Phycol. 19: 425-431

Lund, S. (1959). The marine algae of east Greenland II. Geographical distribution. Meddr. Grønland 156: 1-72

Mann, K. H. (1972). Ecological energetics of the seaweed zone in a marine bay on the Atlantic coast of Canada. I. Zonation and biomass of seaweeds. Mar. Biol. 12: 1-10

Mathieson, A. C., Penniman, C. A., Busse, P. K., TveterGallagher, E. (1982). Effects of ice on Ascophyllum nodosum within the Great Bay Estuary system of New Hampshire-Maine. J. Phycol. 18: 331-336

May, R. M. (1981). Patterns in multi-species communities. In: May, R. M. (ed.) Theoretical ecology (2nd ed.). Sinauer Associates, Sunderland, Massachusetts, p. 197-227

Munda, I. M. (1975). Hydrographically conditioned floristic and vegetation limits in Icelandic Coastal waters. Botanica mar. 18: 223-235

Norton, T. A., Hiscock, K., Kitching, J. A. (1977). The ecology of Lough Ine XX. The Laminaria forest at Carrigathorna. J. Ecol. 65: 919-941

O'Clair, C. E., Hanson, J. L., Myren, R. T., Gharrett, J. A., Merrell, T R., Jr., MacKinnon, J. S. (1979). Reconnaissance of intertidal communities in the eastern Bering Sea and the effects of ice-scour on community structure. Environmental Assessment of the Alaskan Continental Shelf, Final Report of the Principal Investigators, Vol. 10: Biological studies. US Dept. Interior, Bureau of Land Management, p. 1-419

Pearse, J. S., Hines, A. H. (1979). Expansion of a central
California kelp forest following the mass mortality of sea urchins. Mar. Biol. 51: 83-91

Price, J. H. Farnham, W. H. (1982). Seaweeds of the Faroes 3: Open shores. Bull. Br Mus. nat. Hist. (Bot.) 10: 153-225

Probyn, I A., Chapman, A. R. O. (1982). Nitrogen uptake characteristics of Chordaria flagelliformis (Phaeophyta) in batch mode and continuous mode experiments. Mar. Biol. 71: $129-133$

Probyn, T A., Chapman, A. R. O. (1983). Summer growth of Chordaria flagelliformis (O. F. Muell.) C. Ag.: Physiological strategies in a nutrient stressed environment. J. exp. mar. Biol. Ecol. 73: 243-271

Sandeman, W. J. (1982). Variation in oceanographic parameters at a site in Conception Bay, Newfoundland during the period June 25, 1980 to September 28, 1981. Memorial Univ. Nfld. B. Sc. (Hons.) thesis, St. John's, Newfoundland

Sokal, R. R., Rohlf, F. J. (1969). Biometry. W. H. Freeman \& Co., San Francisco

Sousa, W. P. (1979a). Experimental investigations of disturbance and ecological succession in a rocky intertidal algal community. Ecol. Monogr. 49: 227-254

Sousa, W. P. (1979b). Disturbance in marine intertidal boulder fields: the non-equilibrium maintenance of species diversity. Ecology 60: 1225-1239

Sousa, W. P. (1984). The rôle of disturbance in natural communities. A. Rev. Ecol. Syst. 15: 353-391

South, G. R. (1983). Benthic marine algae. In: South, G. R. (ed.) Biogeography and ecology of the island of Newfoundland. Dr. W. Junk Publishers, The Hague, p. 385-420

South, G. R., Hooper, R. G. (1980). A catalogue and atlas of the benthic marine algae of the island of Newfoundland. Memorial Univ. Nfld. Occ. Pap. Biol. 3: 1-136

Steele, D. H. (1975). Marine climate and the biogeography of the surface waters in the northwest Atlantic. Naturaliste can. 102: 189-198

Stephenson, T. A., Stephenson, A. (1972). Life between tidemarks on rocky shores. W H. Freeman \& Co., San Francisco

Tanner, C. E. (1981). Chlorophyta: life histories. In: Lobban, C. S., Wynne, M. J. (ed.) The biology of seaweeds. Bot. Monogr. 17, Blackwell Scient. Publ., Boston, p. 218-247

Taylor, W. R. (1957). Marine algae of the northeastern coast of North America. Univ. Michigan Press, Ann Arbor

van der Meer, J. P. (1981). The life history of Halosaccion ramentacium. Can. J. Bot. 59: 433-436

Whittaker, R. H. (1965). Dominance and diversity in land plant communities. Science 147: 250-260

Wilce, R. T. (1959). The marine algae of the Labrador Peninsula and northwest Newfoundland (ecology and distribution). Bull. natn Mus. Can. 158. Biol. Ser. No. 56, p. 1-101

Wilhm, J. L. (1968). Use of biomass units in Shannon's formula. Ecology 49: 153-156 